\title{
A HEBREW EXEGESIS OF ISAIAH 62:1-5 THE RESTORATION OF ZION
}

\author{
Philip Suciadi Chia' ${ }^{1)}$, Juanda ${ }^{2)}$ \\ 1) Southern Baptist Theological Seminary - Kentucky USA \\ E-mail:pchia275@students.sbts.edu \\ 2) Evangelical Theological Seminary of Indonesia - Surabaya \\ E-mail: juanda@sttii-surabaya.ac.id
}

\begin{abstract}
In this study, spiritual, social-ethic and political background will be scrutinized to assist to understand Isaiah chapter 62 comprehensively. Spiritual life of God's people is declined in the book of Isaiah because of idolatries and nations. Hebrew people make idols out of trees and worship pagan wooden idols (40:18-20; 44:9-20). Isaiah employs prophetic images for the covenant-breaking idolatry and worship of other gods by adultery and illicit sexual intercourse. It is clear that Isaiah is not exclusively interested in the interpersonal and social relationship structures within Israel. He is also concerned with the broader canvas of international politics.
\end{abstract}

Keywords: Exegetical, Isaiah, Restoration

\section{EXEGETICAL OUTLINE}

The restoration of Zion (1-5).

A. Yahweh's providence is declared in negative statement (1a-b).

B. Yahweh's blessing in areas of His people life (1c-5).

a. Recovery among His people (1c-d).

b. Vindication among the nations (2).

c. Elevation by God (3).

b.' Vindication among the nations (4).

a.' Recovery among His people (5).

\section{TRANSLATION}

v. 1 For the sake of Zion, I will not be silent And for the sake of Jerusalem, I will not be quiet Until her righteousness goes forth like brightness And her salvation burns out like torch

v. 2 Then the nations will see your righteousnessAnd all kings your glory And to you will be called, a new name which mouth of YHWH will establish

v. 3: And you will be a beauty crown in the hand of YHWH A royal diadem in the palm of your God

v. 4: And to you will not be said again, ForsakenAnd to your land will not be said again, Desolate Because to you will be called, my delight $i s$ in herAnd to your land 
Journal Theology (Kerugma)

E-ISSN: 2622-0962

P-ISSN: 2621-8038

is married ${ }^{1}$ Because $\mathrm{YHWH}$ delights in you and your land will be married.

v. 5: For young man will marry with a virgin Your sons will marry with you And the rejoicing of bridegroom over the bride So, your God will rejoice over you.

\section{HISTORICAL BACKGROUND}

In this study, spiritual, social-ethic and political background will be scrutinized to assist to understand Isaiah chapter 62 comprehensively. Spiritual life of God's people is declined in the book of Isaiah because of idolatries and nations. Hebrew people make idols out of trees and worship pagan wooden idols (40:18-20; 44:9-20). ${ }^{2}$ In addition to idolatry as such, Isaiah also mentions a number of different cultic sites of various kinds: the sacred trees and

\footnotetext{
${ }^{1}$ To take possession of a woman as bride or wife, to marry.

${ }^{2}$ Although the idol passage are particularly noteworthy, idolatry and its dangers are a continuing interest of the book as a whole. Among other things, this is evidenced by the large number of different words used in Isaiah to denote idols. There are nine terms that Isaiah uses to describe idolatry. Elil occurs 8 times $(2: 8,18,20 ; 10: 10,11 ; 19: 1,3 ; 31: 7)$ and Isaiah employs this word for idol. Atsav and otsev, both also meaning idol, occur three times between them in 10:11, 46:1 and 48:5 and a further synonym, aven is found in 66:3. In addition, there are words which describe specific forms of image such as pasil (4 times, in 10:10;21:9; 30:22; 42:8), and its cognate pesel (the most commonly occurring of these words in Isaiah, appearing 9 times, all in 40-55, 40:19, 20; $42: 1744: 9,10,15,17 ; 45: 20 ; 48: 5)$, which both mean "graven image", and two words for "molten image", masekah (30:22 and 42:17) and nesek (41:29 and 48:5). Furthermore, the root chmd, meaning "desire", and hence "object of desire", is used in the context of pagan worship in 1:29 and 44:9, and elohim is used in its plural sense, "gods", in 8 verse (21:9; 36:18, 19, 20; 37:12, 19 (twice); 41:23 and 42:17). Further discussion see Andrew Davies, Double Standards in Isaiah Re-evaluating Prophetic Ethics \& Divine Justice (Netherlands, Leiden: Koninklijke Brill, 2000), 95-96.
}

${ }^{3}$ Isaiah implies, some sort of fertility rites where the gardens which become centers for pagan sacrifices $(1: 10-15 ; 2: 8 ; 10: 11 ; 43: 22-24){ }^{3}$ Isaiah employs prophetic images for the covenant-breaking idolatry and worship of other gods by adultery and illicit sexual intercourse. ${ }^{4}$ J.D. Smart also adds that their spirituality is inclined to assume that the survival of their city depended on their defensive measures or diplomatic activity than God. ${ }^{5}$

From roughly 810 until 750 B.C, Judah had enjoyed a peace and prosperity, both economic and military expansion, they had not known since the time of Solomon. ${ }^{6}$ However, these affluences were enjoyed by wealthy class only. ${ }^{7}$ Oppression goes right to the heart of Israelite society and the ones, who are in a position of power in society, able to do the oppressing. The poor were

people "burn with lust" (57:5; see also 1:29; 65:3; $66: 17)$; the sacred sites on the mountains (57:7) and in the valleys (57:6); as well as the Asherah poles (asherim) and altars $(17: 8 ; 27: 9 ; 36: 7 ; 65: 3)$ where sacrifices are offered to foreign deities.

${ }^{4}$ Susan Ackerman notes that the similarity between the Hebrew words for the two places where sexual and spiritual covenant relationship are established and broken, for that matter - mishkav, "bed" (vv. 7, 8), and the common word for the "shrine", mishkan. Susan Ackerman, 'Sacred Sex, Sacrifice and Death: Understanding a Prophetic Poem', Bible Review 6 (Feb. 1990), 39.

${ }^{5}$ Isaiah reminds them of Yahweh's promise to David and $\mathrm{He}$ is the only one worth calling refuge and protection. Those nations deserve neither fear nor reliance. J. D. Smart, History and Theology in Second Isaiah (Philadelphia: Epworth, 1965), 263.

${ }^{6}$ John N. Oswalt, The Book of IsaiahChapter 1-39 (Grand Rapids, Michigan: William B. Eerdmans Publishing Company, 1986), 5.

${ }^{7}$ The taxation and exploitation of the trade routes from north to south through the land bridge of Palestine cuase rapid economic growth, even extravagance for the wealthy class. 
exploited and abused. ${ }^{8}$ This is including the denial of the right proper access of poor and underprivileged to the judicial system.

It is clear that Isaiah is not exclusively interested in the interpersonal and social relationship structures within Israel. He is also concerned with the broader canvas of international politics. ${ }^{9}$ During Isaiah ministry, it was a time of great political turmoil for the nation of Judah because facing the opposition that coming from the north and east. The leaders of Jerusalem tend to rely on alliances and political relationship to get assistance. Nevertheless, the political agenda of Isaiah is "quietness and confidence", "returning and repentance" (30:15), reliance upon Yahweh's protection. All of the nations are Yahweh's agents, ${ }^{10}$ and Isaiah believes also that Yahweh expect all the nations of the earth to acknowledge his dominion, to serve and worship him $(2: 2-24 ; 25: 3)$, to reverence him and tremble at his presence (64:2), and that, to this end, Yahweh proposes to send emissaries to the furthest nations on earth who have not heard his name, so that they too might come to Jerusalem and worship him (66:18-20). ${ }^{11}$

\footnotetext{
${ }^{8}$ The particular concern God expresses for the poor in 3:14-15 is not unique, for the poor and also widows and orphans are the most notable among the small number of groups whose needs are particularly addressed

${ }^{9}$ Davies elucidates that the term of politics is relationship between nations and empires on a global basis. Davies, Double Standards in Isaiah Re-evaluating Prophetic Ethics \& Divine Justice, 59 .
}

${ }^{10}$ The nations are Yahweh's agents in bringing disaster to Judah. This is the connection in which the nations first appear as they have devastated Judah because it turned its back on Yahweh. The fist of the great Middle Eastern empires, Assyria, is the means of disaster that stops one step short of bringing the

\section{COMMENTARY}

In the concentric structure of chapters 5666 , Isaiah now moves out from the climax of his message to work back through his previous themes in the light of the vision of the Anointed One. In this process chapter 62 corresponds to chapter $60 \mathrm{but}$, though there is a similarity of theme, more is involved than repetition of the earlier message. Attention reverts from the Messiah's mission and its impact on the well-being and conduct of the population of Zion, to focus again on the city as a whole.

However, whereas we might have expected chapter 62 to expand on the earlier description of Zion's consummate glory, the prophet's viewpoint in this chapter is in fact prior to that of chapter 60 . What he sees follows on from the vision of 61:10-11, where righteousness and praise spring up before all the nations. The underlying note is the guaranteed nature of what will take place, and the chapter reassures the people about the certainty and imminence of Yahweh's saving intervention by explaining something of how that process will work out. $^{12}$

Chapter 62 continues the thoughts of chapter 60 and 61, particularly 61:10-11. The theme of light, revelation of Zion's righteousness and salvation to the nations, marriage joy, relief from oppression and

state down. The second, Babylon, takes the one extra step. The extent of Yahweh's sovereignty is underlined by the fact that it can also influence the way the nations can bring disaster to each other at points that do not directly involve Judah (19:1). On the other hand, nations can be also Yahweh's agents in delivering and restoring Judah. Further discussion read John Goldingay, New International Biblical Commentaryon Isaiah (Peabody, Massachusetts: Hendrickson Publishers, Inc. 2001), 21.

${ }^{11}$ Davies, Double Standards in Isaiah Re-evaluating Prophetic Ethics \& Divine Justice,60-83.

${ }^{12}$ Stanley M. Horton, Isaiah (Springfield, Missouri: Gospel Publishing House, 2000), 442. 
restoration of the land are all prominent. ${ }^{13}$ Scholars agree fairly widely about the structure of the materials in the chapter. The first stanza is verse $1-5$, the second is verse 6-9 and the final one is 10-12. As mentioned above on chapter $60: 10-12$ seem to provide conclusion to chapter 60-62. In language reminiscent of 40:1-3 and 52:7-12, they demonstrate the trustworthiness of the promises by calling the people to acts of faith. Both the preceding stanzas begin with God speaking out to discouraged people. ${ }^{14}$

\section{THE RESTORATION OF ZION (1-5)}

\section{A. Yahweh's providence is declared in negative statement (1a-b)}

This verse is opened by לִמשֶ which has a function to declare the advantage of Zion. In short, this chapter is commenced that everything what God announces to do, it is for the benefit of Zion only. ${ }^{15}$ On the

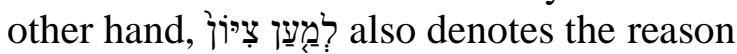

\footnotetext{
${ }^{13}$ The chapter seems to be particularly concerned with the question raised in 61:11: how sure can one be that these glorious promises will actually come true? Chapter 60, in particular, represents the new Jerusalem as an accomplished fact. But that was still in the future from the hearer's point of view. Will it really happen? This chapter reiterates and amplifies the affirmation of 61:11 that indeed it will.

${ }^{14}$ John Oswalt, The book of Isaiah. Chapter 40-66 (Grand Rapids, Michigan: Wm. B. Eerdmans Publishing Co., 1998), 577.

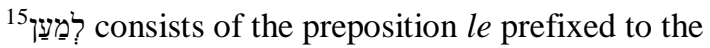
noun maan. William elucidates that if the object of this preposition a person, then it will be translated as for the sake of (for). In short, it emphasizes on advantage for Zion (Jerusalem). Ronald J. Williams, Williams' Hebrew Syntax (Canada: University of Toronto, 2007), 133.

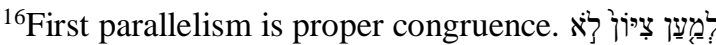

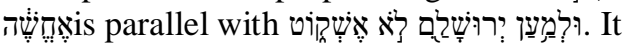 begins with prepositions, followed by object, particle negative and verb (plus subject). They have the congruities both in structure of the sentences and grammatical parallelism.

for what God will bring into for the sake of Zion. Isaiah presents the idea of verse $1 \mathrm{ab}$ in parallelism. ${ }^{16}$ Yahweh's providence is codified in synonymous parallelism for the sake of southern kingdom, he will not silent. ${ }^{17}$ The verbs of the first clauses are found in 18:4; 42:14 and 57:11 with God as the subject. The context (verse 2-5 and 6c9) also denotes that verse one as a part of prophetic comments on the divine assertions. ${ }^{18}$ Yahweh is alleged to have long kept silent and stayed his saving hand $(42: 14 ; 57: 11 ; 64: 22 ; 65: 6) .{ }^{19}$ The verb "keep silent" is often used for the absence of divine revelation and activity (42:14; $57: 11 ; 64: 12 ; 65: 6)$. Based on historical background studies, the silence of Yahweh is caused by degradation of their spiritual life. However, when Yahweh is not silent, he effectively intervenes to implement

\footnotetext{
${ }^{17}$ There is a disputation regarding to the person who will not be passive until restoration of Zion. Many $20^{\text {th }}$-century commentators (e.g., Westermann) have concluded that these words are those of prophet, who asserts that he will continue to intercede for Zion and Jerusalem until God brings the promises to pass (6c-7). Claus Westermann, Isaiah 40-66 (Westminster: John Knox Press, 1969), 371-2. This view has s support from stories of the Bible such as Moses (Deut. 9:13-19) and Amos (Amos 7:1-6) who intercede for his people. Michael Thompson, Isaiah 40-66 (Ivatt Way, Peterborough: 2001), 153. Goldingay states that this is Isaiah commitment to prayer. Oswalt, The book of Isaiah. Chapter 40-66, 578. On the other hand, most earlier writers (e.g., Kimchi) considered that it was God speaking here, as in verse $6 \mathrm{ab}$, promising that, despite his apparent silence, he was actively working to bring about the bright dawn.

${ }^{18}$ Edward J. Young, The book of Isaiah 40-66 (Grand Rapids, Michigan: William B. Eerdmans Publishing Company, 1972), 467.

${ }^{19}$ John Schullion, SJ, Old Testament Message: A Biblical-Theological Commentary on Isaiah 40:66 (Wilmington, Delaware: Michael Glazier, Inc, 1982), 182 .
} 
change. ${ }^{20}$ This synonymous parallelism has a function as the main idea and verse $1 \mathrm{~cd}$ is serving as the adverb of time. It denotes by the using of preposition that something occurs up to the time indicated by its object or, rarely, during the time indicated by its object.

\section{B. Yahweh's blessing in areas of His people life (1c-5)}

In this section, Isaiah points out the various blessings that Zion will achieve such as inside of the Zion, amongst the nations and before God. All of these blessings are presented in chiasmus.

\section{a. Recovery among His people (1c-d)}

Verse $1 \mathrm{~cd}$ indicates time in chiasmus which has a function to add greatly to the effectiveness of the statement. ${ }^{21}$ At the time of speaking, Zion seems to be hidden or at least unnoticed, but when Isaiah reveals that God will not silent until her righteousness will go out like brightness. ${ }^{22}$ The meaning of righteousness is not limited by vindication only, ${ }^{23}$ this parallelism out not limit the reference of the term so much. ${ }^{24}$ The whole context of chapter 56-66 shows that something more than "vindication" (with its suggestion that Israel somehow deserves its deliverance) is intended. The righteousness of God is going to be seen in

\footnotetext{
${ }^{20}$ John L. Mackay, Isaiah 40-66 (Faverdale North, Darlington: MPG Books Group, 2009), 530
}

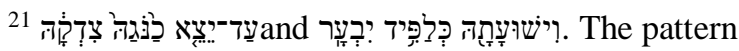
is verb - object - subject and subject - object verb.

\section{${ }^{22} \mathrm{God}$ is the reason and the only source for Zion's restoration.}

\footnotetext{
${ }^{23}$ The NRSV translates sidqa with vinditcation here, probably because it is paralleled by "salvation".

${ }^{24}$ See also on "glory" in verse 2.
}

the character of the saved Israel. This understanding is confirmed by the used of ذف‥ ${ }^{25}$ This word appears in 59:9, which uses the absence of brightness to express the absence of justice and righteousness in the Israelite community. ${ }^{26}$

BDB and HALOT lexicon give the fully meaning of ישיוּעת B. BDB says that this salvation is derived from God and that salvation belongs to (for) Zion (HALOT). ${ }^{27}$ The last clause may literally be rendered as a lamp it burns (burning lamp). The imperfect is joined to the noun lamp without a relative, and so expresses a general attribute belonging to the noun. ${ }^{28} \mathbf{b}$. Vindication among the nations (2)

Verse 2 is serving as a climax of Zion's restoration from preceding verse. First verse pictures the condition of Zion is unnoticed (before God's intervention), then she will be restored (62:1) even God will make her restoration be seen amongst the nations. (62:2). Zion's deliverance will reach out the whole world and she will be noticeable.

In this part, Isaiah presents three suffixes of second person feminine singular which represent three blessings for Zion. The usage of feminine forms here has a function to personify Southern Kingdom as a woman whose loss of husband and family (49:14; 66:7). However, by divine intervention, she will be more than

\footnotetext{
${ }^{25}$ The preposition ?ִ compares righteousness to brightness and word נגֵֵ כometimes is used of soft and mild light as in 50:10 and 60:19.

${ }^{26}$ Oswalt, The Book of Isaiah Chapter 40-66, 578

${ }^{27}$ Francis Brown, S. R. Driver, and C. A. Briggs, $A$ Hebrew and English Lexicon of the Old Testament (Oxford: Clarendon Press), 447, Ludwig Koehler and Water Baumgartner, The Hebrew and Aramaic Lexicon of Old Testament, 5 Vols. (New York: E. J Brill, 1994), 4038

${ }^{28}$ This construction appears several times in Isaiah. Young, The Book of Isaiah Chapter 40 through 66 , 468.
} 
restored. ${ }^{29}$ First suffix denotes that the nations will see her righteousness.

The second suffix is in second clause

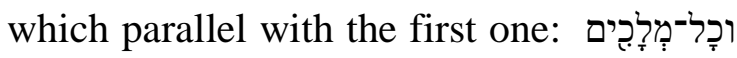

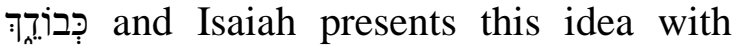
ellipsis. ${ }^{30}$ It means that not only the nations will see her righteousness but also all kings will see her glory. This is a fulfillment that all the nations of the earth to acknowledge his dominion through restoration of Zion. This is another confirmation of the promises of 60:1-9 that the nations will see the reflected glory of God in Zion. To stress his point, the prophet say all kings will see it. ${ }^{31}$ Her glory will be as a candle to the sun compared to the Light that will dawn in Israel.

The third suffix, which is combined with preposition ?,$^{32}$ is the third blessing on this verse. The pual stem implies that Zion will be the object of declaration of her own name. ${ }^{33}$ The nations and kings will not only see her salvation but also confess the new state of Zion. ${ }^{34}$ The manifestation of her glory will be a change of her condition and character as evidenced by a new name. ${ }^{35}$

\footnotetext{
${ }^{29}$ Mackay, Isaiah 40-66, 531.

${ }^{30}$ Isaiah omits the verb the first verb has a double duty to perform. F. I. Andersen, salience, implicature, ambiguity and redundancy in clause-clause relationships in Biblical Hebrew. InBiblical Hebrew and Discourse linguistics, ed. R.D Bergen (Winona Lake, IN: Eisenbrauns, 1994), 113-4.
}

\footnotetext{
${ }^{31}$ This must include not only the petty kings of places like Ammon, Edom and Philistia, but also the emperors of the world like the kings of Assyria, Babylonia and Persia.

${ }^{32}$ Indirect object of?
${ }^{33}$ There is a possibility that the omission of subject here because the subject itself is clear from the context: nations and all kings.

${ }^{34}$ This is not only escalation but Isaiah seems to depict the wholly responses of nations in terms of her salvation. They will not only see (Isaiah prefers use this word, instead of hear, which functions to give a
The proclamation of a new name for Zion indicated the new condition and character that God's salvation will provide for her. That this is solely the work of God is expressed in the final colon by statement the very mouth of the Lord has designated the name. ${ }^{36}$

\section{c. Elevation by God (3)}

Before the announcement of the new names from the old one, the prophet takes aside the discussion of Zion's name and introduces another image to convey the status of Israel before God. ${ }^{37}$

Another feminine suffix appears here to reveal a new blessing. This blessing is presented by synonymous parallelism and ellipsis. ${ }^{38}$ You will be crown of beauty, which is parallel with turban of kingdom, in the hand of Yahweh (parallel with palm of God). היה here introduces a new state (existence) of Zion. עִטָרָרה means a garland of glory or crown to picture the honor of Jerusalem. צִּנוּף turban of the king. From these definitions,

punch of the idea of Zion's restoration) but also they will testify it by their words.

\footnotetext{
${ }^{35}$ In Israelite culture, as in that of the entire Near East, name and character were intimately associated. This is the reason for the importance attached to the naming of children $(7: 3,14 ; 8: 3 ; 9: 5)$. It also explains the significance of important name changes in the patriarchal accounts (Gen. 17:5; 32:38).
}

${ }^{36}$ Young, The Book of Isaiah Chapter 40 through 66 ,
469 . The major significant of this clause is God
himself who gives this new name, not nations. The
minor significant is all the nations will call Zion the
same name which God designates. It can be
understood either God will put this new name on the
mouth of nations or this is as a manifestation of the
repentance of nations to God.

${ }^{37} \mathrm{I}$ call this as $\mathrm{X}$ of chiasmus pattern. Before announcing the new names amongst the nations, Isaiah declares a new status of Zion before God.

${ }^{38}$ Ellipsis here is omission of
${ }^{39} \mathrm{BDB}, 742$. 
Isaiah intends to set forth the greatest beauty on earth by restoring the glory and honor of Zion and so the Zion is displayed as the masterwork of Lord (51:6; 65:17).

Preposition ?ִ̣ indicates location of the crown and turban is in Yahweh hand. ${ }^{40}$ Oswalt interprets that the people of God, Zion (Jerusalem), are in his hand, in his care and under his control. Notwithstanding, they are not in his hand as slaves or lumps of wood or stone. They are in God's hand as a priceless possession, a thing of delight, honor and beauty. ${ }^{41}$ So that, Zion does not need to fear that God will forget his promises concerning her; she is his dearest possession (Pro. 12:4a). ${ }^{42}$

\section{b.' Vindication among the nations (4)}

In this verse, Isaiah employs in synonymous parallelisms for the first two lines. The parallelisms in first line, Isaiah presents the structure of first sentence is a little bit different with the second one. The first sentence commences with verb and the last sentence embarks on object. ${ }^{43}$ For the second line of this verse, it has two

\footnotetext{
${ }^{40}$ Interestingly, the location of crown and turban usually on someone's head not hand.

${ }^{41}$ God is not restoring them to himself grudgingly or mechanically; he does do as one would a piece of precious jewelry.
}

${ }^{42}$ Oswalt, The Book of Isaiah Chapter 40-66, 579. However, beside to the imagery crown in God's hand indicates how completely Yahweh had controlled the change which has occurred in Zion and how the city continued to be guarded and governed by Yahweh himself, Mackay also points out that there is also evidence that at wedding ceremonies crowns were worn by bridegroom and bride. In the light of $61: 10$ and $62: 4-5$, it may well be that marriage symbolism is to be identified in this passage, and that might also be a factor in the assignation to Zion of a new name $(62: 2)$.

${ }^{43}$ The first sentence is $\mathrm{V}(\mathrm{S})-\mathrm{O}-($ Adverb $)-\mathrm{OC}$ and the second is $\mathrm{O}-\mathrm{V}(\mathrm{S})-\mathrm{A}-\mathrm{OC}$. functions. ${ }^{44}$ Firstly, for its line itself, it serves as a synonymous parallelism with the first verb has double functions. ${ }^{45}$ On the other hand, this line also has a function to contrast the idea of the first line in order to give a fuller meaning. In short, the first two lines is the promise of the new name for Zion which is conveyed by negatively and positively. The last line of this verse, Isaiah seems to utilize chiasmus to articulate his intent as the substantiation of the second line. ${ }^{46}$ Isaiah's pattern is still noticeable in this verse with suffix second person feminine singular denotes God's blessing for Zion. The first line, Isaiah conveys the negative idea by presenting negative phrase (לאיאיאָָמָר) as the marks. The niphal stem of אמר implies passive meaning with דָ̦ function as indirect object. ${ }^{47}$ It has the same connotation with verse two that the restoration, which God brings, will be testified by all of the nations.

The nations and all kings will not name Zion's old name again as deserted and desolation. ${ }^{48}{ }^{8}$ עִ עִmeans abandoned or

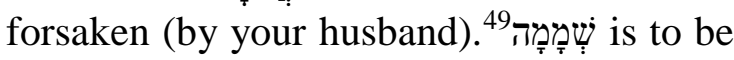
understood as barren as in 54:1. The

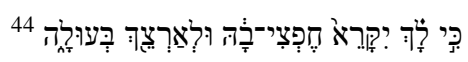

${ }^{45}$ Because the second sentence, on the second line, does not have verb (ellipsis: omission of the verb).

${ }^{46}$ With omission of the subject: Yahweh. Westermann, Isaiah 40-66, 376.

${ }^{47}$ The use of the passive of "to say" is characteristic of Isaiah $(4: 3 ; 19: 18 ; 32: 5 ; 61: 6)$, whereas it occurs only three times in Jeremiah and once in Hosea and Zephaniah.

${ }^{48}$ The old name for Jerusalem, uttered in contempt, had been "forsaken" (Jer. 30:17). The nations could mock and tease Israel about the failure and ineffectiveness of Yahweh (Isa. 37:4, 24). Jerusalem is marked as a city abandoned and without any protective God (Lam. 5:20).

${ }^{49} \mathrm{As}$ in 60:15 and 54:6, from which the metaphor was taken. BDB confirms this personification between wife and her husband. BDB, 736. 
historical studies denote that the people of Zion had forsaken Jehovah. They do sexual adultery (spiritually) and rely on other nations; therefore, He had forsaken and abandoned her. ${ }^{50}$ Deserted and desolation had been the result of the sins committed in the land; a divine judgment had been brought upon it. ${ }^{51}$ But now, says the silencebreaking God, the season of abandonment is over. She will be named her old names by nations and kings anymore.

The second line has an opposite content with the first one, but it conveys a fuller idea. ${ }^{52}$ This opposite content is strengthened by particle which serves as a concessive (although). In this line, Isaiah conveys the change of name of Zion which signals a new identity, a new relation, a new chance for life in the world. ${ }^{53}$ The first name

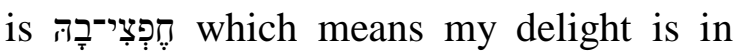
here. This is a descriptive of the new (intimate) relationship that stresses the fact that God's concern for His people because of His love ${ }^{54}$ Her second name is married. ${ }^{55}$ The imagery of "marriage" and "delight" is thus a dramatic counter to the sense of abandonment and forlornness. God will protect Zion and she will be no longer abandoned.

${ }^{50}$ This idea appears in Deut. 28:15; II Chron. 15:2; Isa. 51:19-20.

${ }^{51}$ Leviticus 26:23-24, 31-33; Jeremiah 12:7-13.

${ }^{52}$ The differences are including the omission particle negative on the second line, old name as a contrast to new name and the changing of verb from קרא to However, the second line still keeps the object

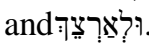

\footnotetext{
${ }^{53}$ Walter Brueggemann, Isaiah 40-66 (Louisville, Kentucky: Westminster John Know Press, 1998), 220.

${ }^{54}$ Paul T. Butler, Isaiah III (USA: College Press Publishing Company, 1978), 434.

${ }^{55}$ HALOT Lexicon utters that בעל has a meaning to take possession of a woman as bride or wife. Brueggemann adds that this term is cannot be separated from the imagery of divorce or widowhood in Isaiah 54:4-6 which is transposed into an agricultural term for a land barren and unproductive.
}

The last line of this verse is presented by chiasmus with omission of Yahweh as the subject. ${ }^{56}$ commences this line to provide the reasons of changing old names to new names. ${ }^{57}$ The first reason is

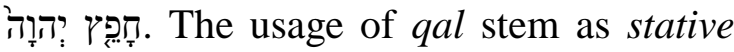
here has a function to denote a state or condition. The location of particle ?ִ conveys that when Yahweh in Zion, he delights (state). The last reason is your land will be married to him. It conveys that the land of Zion is belonging to God.

\section{a.' Recovery among His people (5)}

Verse 5 explains the previous verse with illustrations. Westermann states that verse 5 is the completion of third line with chiasmus. ${ }^{58}$ Therefore, the introductory has a function as comparison to elucidate the meaning of preceding verse. The wedding is illustrated by two marriages: a young man to a virgin and your sons will marry you. ${ }^{59}$ These illustrations use a lyrical assertion of joy that is like the unrestrained delight of bride and bridegroom. ${ }^{60}$ In the quite large number of Old Testament passages which use the metaphor of marriage to describe relationship with God,

Now this people isreloved and the city is restored; the land is recovered for fruitfulness and productivity. He believes that the relational aspect of covenant fidelity has as a counterpart the covenantal fruitfulness of the land. Brueggemann, Isaiah 40-66, 221.

${ }^{56} \mathrm{~S}-\mathrm{V}-\mathrm{IO}$ and $\mathrm{O}-\mathrm{V}-(\mathrm{S})$.

${ }^{57}$ These reasons are repetitions to the second line. The objects and the new names on the second line are reiterated here.

${ }^{58}$ The first line of verse 5 is parallel to the third line of verse 4 on the second part. The second line of verse 5 is parallel to the third line of verse 4 on the first part. Westermann, Isaiah 40-66, 376.

${ }^{59}$ Further discussion can be seen at textual criticism studies.

${ }^{60}$ Brueggemann, Isaiah 40-66, 221. 
God's partner is always a community and never an individual. This means that the relationship is invariably expressed from the divine point of view, as in the words mentioned above, "so does your God rejoice over you", and never from the human. ${ }^{61}$ The question has been raised as to whether this means the sons of Zion marry Zion or the sons of the land marry the land. The emphasis here is the joyous intimate relationship between the sons of Zion, who are Yahweh's people, and the land, which is His holy mountain $(57: 13 ; 60: 21 ; 61: 7)$. As a young man marries a virgin and dedicates himself to protecting and caring for her honor, so the sons of Zion dedicate themselves to the honor of Yahweh's land and people. The relationship will be pure and chaste. And as the bridegroom rejoices over the bride, over their pure, divine love, so God will rejoice over her, over Zion's marriage to the land, His holy mountain. ${ }^{62}$

\section{REFERENCES}

[1] Ackerman, Susan. 'Sacred Sex, Sacrifice and Death: Understanding a Prophetic Poem', Bible Review 6 (Feb. 1990).

[2] Andersen, F. I. 'Salience, Implicature, Ambiguity and Redundancy in clauseclause relationships in Biblical Hebrew'. InBiblical Hebrew and Discourse linguistics, ed. R.D Bergen. Winona Lake, IN: Eisenbrauns, 1994.

[3] Blenkinsopp, Joseph. Isaiah 56-66 A New Translation with Introduction and Commentary. New York: The Anchor Bible, 2003.

[4] Brown, Francis S. R. Driver, and C. A. Briggs, AHebrew and English Lexicon of

\footnotetext{
${ }^{61}$ Westermann, Isaiah 40-66, 373.
}

the Old Testament Oxford: Clarendon Press, 1994.

[5] Brueggemann, Walter. Isaiah 40-66. Louisville, Kentucky: Westminster John Know Press, 1998.

[6] Buksbazen, Victor. The Prophet Isaiah. Collingswood, N.J: The Spearhead Press, 1971.

[7] Butler, Paul T. Isaiah III. USA: College Press Publishing Company, 1978.

[8] Davies, Andrew. Double Standards in Isaiah Re-evaluating Prophetic Ethics \& Divine Justice. Netherlands, Leiden: Koninklijke Brill, 2000.

[9] Goldingay, John. New International Biblical Commentaryon Isaiah. Peabody, Massachusetts: Hendrickson Publishers, Inc. 2001.

[10] Horton, Stanley M. Isaiah. Springfield, Missouri: Gospel Publishing House, 2000.

[11] Koehler, Ludwig and Water Baumgartner, The Hebrew and Aramaic Lexicon of Old Testament, 5 Vols. New York: E. J Brill, 1994.

[12] Mackay, John L. Isaiah 4066.Faverdale North, Darlington: MPG Books Group, 2009.

[13] T. Muraoka, A Greek-English Lexicon of the Septuagint. Leuven, Belgium: PEETERS, Warotstraat, 2009.

[14] Oswalt, John N. The Book of IsaiahChapter 1-39. Grand Rapids, Michigan: William B. Eerdmans Publishing Company, 1986.

\footnotetext{
${ }^{62}$ Homer Hailey, A Commentary on Isaiah with Emphasis on the Messianic Hope (Grand Rapids, Michigan: 1985), 498.
} 
Journal Theology (Kerugma)

E-ISSN: 2622-0962

P-ISSN: 2621-8038

[15] , The book of Isaiah.

Chapter 40-66. Grand Rapids, Michigan:

Wm. B. Eerdmans Publishing Co., 1998.

[16] Schullion, SJ, John. Old Testament Message: A Biblical-Theological Commentary on Isaiah 40:66. Wilmington, Delaware: Michael Glazier, Inc, 1982.

[17] Smart, J. D. History and Theology in Second Isaiah. Philadelphia: Epworth, 1965.

[18] Thompson, Michael. Isaiah 40-66.Ivatt Way, Peterborough: 2001.

[19] Westermann, Claus. Isaiah 40-66. Westminster: John Knox Press, 1969.

[20] Whybray, R. N. Isaiah 40-66. Grand Rapids, Michigan: WM. B. Eerdmans Publ. Co., 1975.

[21] Williams, Ronald J. Williams' Hebrew Syntax. Canada: University of Toronto, 2007.

[22] Young, Edward J. The book of Isaiah 40-66. Grand Rapids, Michigan: William B. Eerdmans Publishing Company, 1972. 